\title{
Estudo da farmacodinâmica da vancomicina durante a perfusão pulmonar ex-vivo
}

\author{
Paula Malvezzi Messias', Marcos Naoyuki Samano²
}

Messias PM, Samano MN. Estudo da farmacodinâmica da vancomicina durante a perfusão pulmonar ex-vivo. Rev Med (São Paulo). 2015 jan.-mar.;94(1):59-60.

\section{INTRODUÇÃO}

Em nosso meio, somente $5 \%$ dos pulmões doados são adequados para transplante, em contraste com as taxas mundiais, que aproximam-se dos 15\%. Técnicas de recondicionamento do órgão, como a perfusão pulmonar ex-vivo, são capazes de tornar viáveis pulmões que, inicialmente, seriam inadequados para o transplante, mas seu potencial para o tratamento de pulmões infectados ainda não foi avaliado. Dado que as infecções estão entre as principais causas para o alto índice de rejeição observado, uma técnica de tratamento adequada para esses casos seria de grande valia para aumentar o aproveitamento de órgãos doados. A vancomicina foi escolhida para este estudo por ser um antibiótico eficaz no tratamento de pneumonias por bactérias Gram-positivas, como o S. aureus, agente etiológico comum de pneumonias em doadores de múltiplos órgãos.

\section{OBJETIVO}

Avaliar a concentração da vancomicina na solução de perfusão pulmonar ex-vivo e seu efeito sobre a flora bacteriana Gram-positiva nos pulmões infectados.

\section{METODOLOGIA}

Pulmões inadequados para transplante de cinco doadores de órgãos foram incluídos no estudo por apresentarem sinais de infecção. Cada bloco pulmonar foi colocado na câmara de perfusão e conectado ao sistema de perfusão Xvivo ${ }^{\circledR}$, que foi preenchido com dois litros da solução de perfusão Steen Solution ${ }^{\circledR}$, adicionados de $500 \mathrm{mg}$ de metilprednisolona, 3000 UI de heparina, 500mg de imipenem e $500 \mathrm{mg}$ de vancomicina. A perfusão exvivo teve duração de seis horas, sendo que, ao final de cada hora, a solução de Steen ${ }^{\circledR}$ foi parcialmente reposta e pequenas alíquotas do perfusato foram coletadas para a dosagem da concentração de vancomicina. Também foram colhidos LBA e/ou secreção brônquica no doador e na primeira, terceira e sexta horas de perfusão, os quais foram encaminhados para análise microbiológica e cultura.

\section{RESULTADOS}

As concentrações médias de vancomicina observadas para o final da primeira e da sexta horas de perfusão, foram, respectivamente, $160,5 \mu \mathrm{g} / \mathrm{ml}$ e $76,3 \mu \mathrm{g} / \mathrm{ml}$, valores menores do que os determinados somente pela diluição do perfusato $(250 \mu \mathrm{g} / \mathrm{ml}$ e $109,9 \mu \mathrm{g} / \mathrm{ml})$, mas superiores aos níveis terapêuticos recomendados $(15 \mathrm{a} 20 \mu \mathrm{g} / \mathrm{ml})$.

Em três casos, bactérias Gram-positivas encontradas no LBA ou secreção brônquica coletados antes do início da perfusão não foram mais detectadas no material colhido após a sexta hora de experimento; em um caso, bactérias Gram-positivas não foram encontradas no

\footnotetext{
$1^{\circ}$ lugar Prêmio Painéis - Área Cirurgia no 33 COMU - Congresso Médico Universitário da FMUSP, SP, 31 de out. a 02 de nov. de 2014.

1. Acadêmicos de Medicina da Faculdade de Medicina da Universidade de São Paulo.

2. Orientadores, Faculdade de Medicina da Universidade de São Paulo.
} 
material colhido em nenhum dos tempos; em um caso, as bactérias encontradas no primeiro LBA/secreção brônquica continuaram presentes no material coletado em todos os tempos.

Bactérias Gram-negativas foram detectadas em três casos antes do início da perfusão e, nos três, não foram mais detectadas ao final do experimento. Leveduras foram encontradas no material coletado antes do início da perfusão em quatro casos, mas só persistiram até o final da sexta hora em um deles.

\section{CONCLUSÃO}

A vancomicina parece ser metabolizada nos pulmões infectados, além de inibir o crescimento de bactérias Grampositivas encontradas no LBA. Mesmo com a diluição da solução de perfusão pulmonar, uma única dose de 500mg de vancomicina é suficiente para manter sua concentração acima dos níveis terapêuticos recomendados, durante as seis horas de perfusão. 